\title{
ANALISIS PENERIMAAN PAJAK HOTEL TERHADAP PENINGKATAN PENDAPATAN PAJAK DAERAH DI KOTA PALU
}

\author{
RIZKI RAFYUMAN R. MASSI \\ MUH. FAISAL \\ HUSNAH \\ Jurusan Manajemen, Fakultas Ekonomi, Universitas Tadulako \\ Email: rizkirafyuman@gmail.com
}

\begin{abstract}
This study aims to analyze the level of growth, efficiency, effectiveness, and contribution of the hotel tax on the local tax in Palu. The data used in this study is primary and secondary tax data from 2010 until 2014. The research is conducted at the Department of Local Revenue, Finance, and Asset Management (DPPKAD) of Palu. The analytical tool used is the analysis of the growth, efficiency analysis, analysis of effectiveness, and analysis contributions. The results suggest that the growth of tax collection in Palu City is $52.73 \%$ the percentage seems to increase but the percentage fluctuates. Tax collection in Palu City in the period of 2010-2014 is very effective, which is proved that the hotel tax realization can be achieved over 100\% with the level of effectiveness of $133.05 \%$. The efficiency rate of the hotel tax is very efficient with the efficiency rate of 0.05 or $5 \%$. Hotel tax contribution on the local tax of Palu City in 2010-2014 is 8.16\%, which means that the local tax revenue of $8.61 \%$ in Palu, comes from the hotel tax.
\end{abstract}

Keywords: taxes hotel and local taxes.

Abstrak
Penelitian ini bertujuan untuk menguji tingkat pertumbuhan, efisiensi, efektifitas dan kontribusi pajak hotel terhadap pajak daerah di Kota Palu. Data yang digunakan dalam penelitian ini adalah data primer dan sekunder dengan periode yang di analisis dari tahun 2010 sampai tahun 2014. Penelitian ini dilakukan di Dinas Pendapatan, Pengelolaan Keuangan dan Aset Daerah (DPPKAD) Kota Palu. Alat analisis yang digunakan adalah analisis pertumbuhan, analisis efisiensi, analisis efektifitas, dan analiasis kontribusi. Hasil penelitian memberikan gambaran bahwa pertumbuhan pemungutan pajak hotel di Kota Palu sebesar 52,73\%. Secara riil terlihat meningkat, akan tetapi secara presentase berfluktuasi. Pemungutan pajak hotel di Kota Palu dalam kurun waktu tahun 2010-2014 menunjukan sangat efektif, hal ini terlihat bahwa realisasi pajak hotel dapat dicapai diatas $100 \%$ dengan tingkat efektifitas sebesar $133,05 \%$. Tingkat efisiensi pajak hotel diakatakan sangat efisien dari tahun-ketahun dengan tingkat efisiensi pajak hotel sebesar 0,05 atau 5\%. Kontribusi pajak hotel terhadap pajak daerah kota palu dari tahun 2010-2014 sebesar 8,16\%, ini berarti pendapatan pajak daerah Kota Palu sebesar $8,61 \%$ berasal dari pajak hotel.

Kata Kunci: Pajak Potel dan Pajak Daerah

\section{PENDAHULUAN}

Pembiayaan pemerintah daerah dalam melaksanakan tugas pemerintahan dan pembangunan senantiasa memerlukan sumber penerimaan yang dapat diandalkan. Pembangunan daerah didasarkan atas otonomi daerah dengan mengacu pada kondisi dimana suatu daerah mampu menggali sumber keuangannya sendiri dan seminimal mungkin tergantung pada bantuan pemerintah, sehingga pendapatan asli daerah harus menjadi bagian keuangan terbesar yang didukung untuk kebijakan perimbangan keuangan pusat dan daerah sesuai dalam UU No. 33 Tahun 2004.

Otonomi yang diberikan kepada daerah kabupaten dan kota dilaksanakan dengan memberikan kewenangan yang luas, nyata dan bertanggungjawab kepada pemerintah daerah secara proporsional. Artinya pelimpahan tanggung jawab akan diikuti oleh pengaturan pembagian, pemanfaatan dan sumberdaya nasional yang berkeadilan serta perimbangan keuangan pusat dan daerah. Penerapan desentralisasi sebagai wujud dari otonomi daerah juga menimbulkan permasalahan dalam pembagian keuangan antara pusat dan daerah dimana pelaksanaan tugas dan wewenang masing-masing tingkat pemerintahan memerlukan dukungan pendanaan. Salah satu tolak ukur untuk melihat kesiapan daerah 
dalam pelaksanaan otonomi daerah adalah dengan megukur seberapa besar kemampuan keuangan suatu daerah untuk menyelenggarakan otonomi daerah atau pemerintah sendiri. Sumber keuangan tersebut salah satunya berasal dari Pendapatan Asli Daerah (PAD).

Undang-undang Nomor 28 Tahun 2009, pajak Hotel adalah pajak atas layanan yang disediakan oleh hotel. Pemerintah kota palu selanjutnya menindak lanjuti Undang-undang tersebut yang dituangkan dalam Perda Nomor 1 Tahun 2011 tentang pajak daerah, dimana pada pasal 4 dinyatakan bahwa objek pajak adalah pelayanan yang disediakan oleh hotel dengan pembayaran, termasuk jasa penunjang sebagai kelengkapan hotel yang sifatnya memberikan kemudahan dan kenyamanan, termasuk fasilitas olah raga dan hiburan.

Kota Palu merupakan salah satu kota yang diberi hak otonomi daerah untuk mengatur rumah tangganya sendiri guna melaksanakan pembangunan. Pemerintah dan warga Kota Palu diharapkan mampu mengelola dan memaksimalkan potensi sumber ekonomi yang ada untuk kelangsungan dan kemajuan Kota Palu. Apabila potensi sumber ekonomi di Kota Palu dikembangkan dan ditingkatkan, maka dapat meningkatkan citra daerah dan mampu memaksimalkan pendapatan daerah. Salah satu upaya yang dapat dilakukan pemerintah Kota Palu adalah dengan memaksimalkan pendapatan daerah dari sektor pajak daerah.

Semakin berkembangnya Kota Palu sebagai salah satu kota tujuan wisata dan kota industri membuat daya tarik Kota Palu semakin terlihat jelas. Penggunaan jasa perhotelan dan penginapan akan semakin meningkat yang berdampak pada peningkatan pajak daerah khususnya dari pajak hotel. Berdasarkan hal tersebut, peneliti melakukan penelitian terkait dengan pajak hotel. Penelitian dilakukan di Dinas Pendapatan Pengelolaan Keuangan Dan Aset Daerah (DPPKAD) Kota Palu. Tempat ini dipilih karena DPPKAD merupakan instansi yang mengelola langsung penerimaan pajak daerah khususnya pajak hotel.

Tabel 1 Jumlah Hotel, Pengunjung Dalam dan Luar Negeri Yang Ke Kota Palu Tahun 2010-2014

\begin{tabular}{|c|c|c|c|c|c|}
\hline No. & Tahun & Jumlah Hotel & $\begin{array}{c}\text { Tamu Luar } \\
\text { Negeri }\end{array}$ & $\begin{array}{c}\text { Tamu Dalam } \\
\text { Negeri }\end{array}$ & Total Tamu \\
\hline 1. & 2010 & 62 & 838 & 49.018 & 49.856 \\
\hline 2. & 2011 & 61 & 756 & 48.157 & 48.913 \\
\hline 3. & 2012 & 68 & 1.024 & 47.431 & 48.455 \\
\hline 4. & 2013 & 74 & 1.823 & 113.951 & 115.774 \\
\hline 5. & 2014 & 79 & 852 & 105.455 & 106.307 \\
\hline
\end{tabular}

Sumber:Data Badan Pusat Statistik Provinsi Sulawesi Tengah dan Data Dinas Pariwisata dan Ekonomi Kreatif Kota Palu. (Februari, 2016)

Berdasarkan Tabel 1, Hotel yang berada di Kota Palu tiap tahunnya mengalami penambahan unit. Jumlah pengunjung yang terbanyak terjadi di tahun 2013 dengan jumlah pengunjung sebesar 115.774 orang. Ini tidak lepas karena pada tahun 2013 kota Palu menjadi tuan rumah kegiatan Nasional puncak acara Hari Nusantara sehingga banyak menarik wisatawan dari luar maupun dalam negeri yang berkunjung ke kota palu. Sedangkan di tahun 2014 jumlah pengunjung kota Palu 106.307 orang atau mengalami penurunan sebesar 9.467 orang dari tahun 2013. Akan tetapi jumlah penurunan pengunjung yang datang ke Kota Palu tidak menurunkan jumlah realisasi pajak hotel yang diterima Kota Palu.

Tabel 2 Target dan Realisasi Pajak Hotel Kota Palu Tahun 2010-2014

\begin{tabular}{|c|c|c|c|c|}
\hline No. & Tahun & Target (Rp.) & Realisasi (Rp.) & Growth (\%) \\
\hline 1. & 2010 & 1.488 .241 .000 & 1.703 .852 .495 & - \\
\hline 2. & 2011 & 1.688 .241 .000 & 1.912 .852 .881 & 12.26 \\
\hline 3. & 2012 & 2.235 .000 .000 & 3.414 .632 .416 & 78.51 \\
\hline 4. & 2013 & 3.000 .000 .000 & 4.952 .210 .445 & 45.02 \\
\hline 5. & 2014 & 7.250 .000 .000 & $8.673 .418 .273,64$ & 75.14 \\
\hline
\end{tabular}

Sumber: Data DPPKAD (Dinas Pendapatan Pengelolaan Keuangan Dan Aset Daerah Kota Palu). (Februari, 2016) 
Berdasarkan Tabel 2, realisasi pajak hotel di kota palu terus mengalami peningkatan, dengan tingkat pertumbuhan yang sangat berfluktuatif. Misalnya, pada tahun 2011 realisasi pajak hotel sebesar $12.26 \%$ dan meningkat sebesar $78.51 \%$ ditahun 2012. Akan tetapi pada tahun 2013 tingkat pertumbuhan pajak hotel di kota palu turun keangka 45.02\%. Dengan kata lain, kinerja pendapatan daerah melalui pajak hotel pada tahun 2013 mengalami penurunan dibanding tahun 2012. Akan tetapi kembali meningkat di tahun 2014 sebesar 75.14\%. Hal ini menunjukkan bahwa penerimaan daerah kota Palu melalui pajak hotel makin dapat ditingkatkan setiap tahunnya meskipun belum maksimal.

Berdasarkan uraian pada latar belakang ini, maka tujuan penelitian ini yaitu untuk mengetahui:

1. Tingkat pertumbuhan pajak hotel di Kota Palu.

2. Tingkat efektifitas pajak hotel di Kota Palu.

3. Tingkat efisiensi pajak hotel di Kota Palu

4. Kontribusi pajak hotel terhadap total penerimaan pajak daerah di Kota Palu.

\section{KAJIAN LITERATUR DAN PENGEMBANGAN HIPOTESIS Otonomi Daerah}

Menurut Undang-Undang No.32 tahun 2004 tentang Pemerintah Daerah yang dimaksud dengan otonomi daerah adalah hak, wewenang, dan kewajiban daerah otonom untuk mengatur dan mengurus sendiri urusan pemerintahan dan kepentingan masyarakat setempat dengan peraturan perundangundangan.

\section{Manajemen Keuangan Daerah}

Menurut Halim (2007:330) Pengelolaan Keuangan daerah adalah keseluruhan kegiatan yang meliputi, pelaksanaan, penatausahaan, pelaporan, pertanggungjawaban dan penguasaan keuangan daerah.

\section{Pendapatan Asli Darah (PAD)}

Sebagaimana yang telah diatur di dalam Undang-Undang Nomor 33 Tahun 2004 tentang perimbangan keuangan pusat dan daerah, Pendapatan Asli Daerah (PAD) dapat diartikan adalah pendapatan yang diperoleh daerah yang dipungut berdasarkan peraturan daerah sesuai dengan peraturan perundang-undangan, sumber-sumber pendapatan Asli Daerah (PAD) adalah sebagai berikut:

1. Pajak Daerah

2. Retribusi Daerah

3. Bagian Laba Badan Usaha Milik Daerah

4. Lain-lain Pendapatan Asli Daerah yang Sah

\section{Pajak Daerah}

Pengertian Pajak Daerah menurut Undang-Undang Nomor 28 Tahun 2009 tentang perubahan Undang-Undang Nomor 34 Tahun 2000 tentang pajak daerah adalah iuran wajib yang dilakukan oleh orang pribadi atau badan kepada daerah tanpa imbalan langsung yang seimbang yang digunakan untuk membiayai penyelenggaraan pemerintah daerah dan pembangunan daerah.

Adapun jenis pajak yang dikelola oleh Pemerintah Tingkat I yaitu Propinsi terdiri dari :

1. Pajak kendaraan bermotor

2. Pajak bea balik nama kendaraan bermotor

3. Pajak bahan bakar kendaraan bermotor, dan

4. Pajak pengambilan dan pemanfaatan air bawah tanah dan air permukaan.

Sedangkan untuk jenis pajak di Tingkat II yaitu Kabupaten/Kota terdiri dari :

1. Pajak Hotel

2. Pajak Restoran

3. Pajak hiburan

4. Pajak Reklame

5. Pajak Penerangan Jalan

6. Pajak pengambilan dan pengolahan bahan galian Golongan C

7. Pajak Parkir 


\section{Pajak Hotel}

Sesuai dengan Peraturan Daerah (PERDA) Kota Palu Nomor 1 Tahun 2011 pengertian hotel adalah:

1. Hotel adalah fasilitas penyedia jasa penginapan/peristrahatan termasuk jasa terkait lainnya dengan dipungut bayaran, yang mencakup juga motel, losmen, gubuk pariwisata, wisma pariwisata, pesanggrahan, rumah penginapan dan sejenisnya, serta rumah kos dengan jumlah kamar lebih dari sepuluh.

2. Pajak Hotel adalah Pajak atas pelayanan yang disediakan oleh Hotel.

3. Objek pajak hotel adalah pelayanan yang disediakan dengan pembayaran di hotel

4. Pengusaha hotel adalah Perorangan atau badan yang menyelenggarakan usaha untuk dan atas namanya sendiri atau untuk dan

\section{Subjek Pajak Hotel}

Berdasarkan Peraturan Pemerintah Nomor 65 Tahun 2001 tentang pajak daerah yang dimaksud wajib pajak hotel hanya pengusaha hotel. Padahal secara logika keduanya merupakan wajib pajak. Bagi pembayar hotel merupakan wajib pajak langsung, sedangkan bagi pengusaha hotel merupakan wajib pajak pungut. Pengusaha hotel itu berkewajiban menyetor pajak hotel ini ke kas daerah.

\section{Objek Pajak Hotel}

Bentuk objek pajak hotel yang sebagaimana tertulis dalam Peraturan Daerah Kota Palu Nomor 1 Tahun 2011 meliputi hal-hal sebagai berikut :

1. Fasilitas penginapan atau fasilitas tinggal jangka pendek antara lain gubuk pariwisata (cottage), motel, wisma pariwisata, pesangrahan (hotel), losmen dan rumah penginapan termasuk kost dengan jumlah kamar 10 atau lebih yang menyediakan fasilitas seperti rumah penginapan dengan pelayanan menginap jangka pendek.

2. Pelayanan penunjang antara lain telepon, facsimile, telegram, fotokopi, pelayanan cuci, setrika, taxi dan pengankutan lainnya yang disediakan atau dikelola oleh hotel.

3. Fasilitas olahraga dan hiburan antara lain pusat kebugaran (fitness), kolam renang, tenis, golf, karaoke, pub, diskotik yang disediakan atau di kelola oleh hotel.

4. Jasa persewaan ruangan untuk kegiatan acara atau pertemuan di hotel.

\section{Dasar Pengenaan Pajak Hotel}

Dasar pengenaan pajak hotel adalah jumlah pembayaran yang dilakukan kepada hotel. Pembayaran adalah jumlah yang diterima atau seharusnya diterima sebagai imbalan atas penyerahan barang dan jasa sebagai pembayaran kepada pemilik hotel.

Tarif pajak hotel yang ditetapkan berdasarkan peraturan Pemerintah Daerah Kota Palu Nomor 1 Tahun 2011 yaitu $10 \%$. Pajak hotel yang terutang dipungut di wilayah daerah tempat hotel berlokasi.

\section{Kerangka Pemikiran}

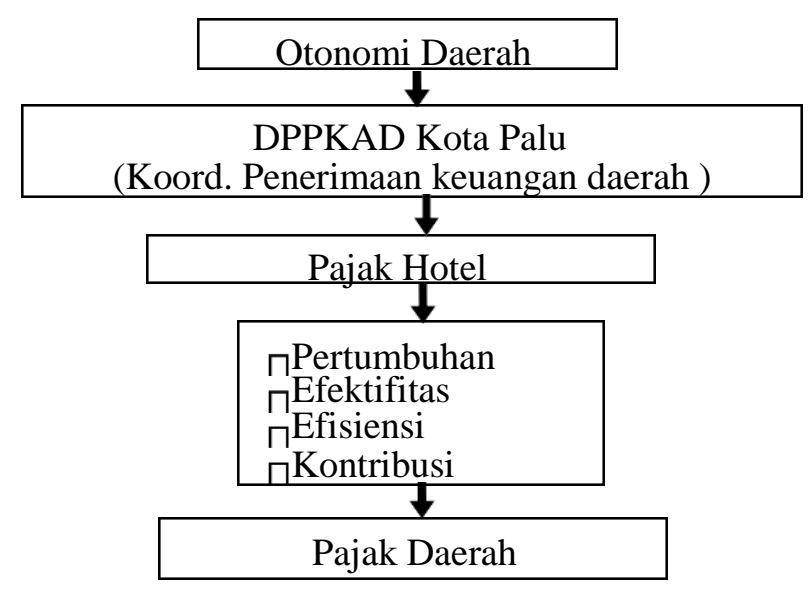

Gambar 1 Kerangka Pemikiran 


\section{METODE PENELITIAN}

Tipe penelitian yang digunakan dalam penelitian ini merupakan studi kasus dengan menggunakan metode analisis deskriptif. peneliti menggunakan jenis penelitian yang bersifat deskriptif mengacu pada bagaimana menata atau mengorganisasi data, menyajikan, dan menganalisis data. Menata, menyajikan, dan menganalisis data dapat dilakukan misalnya dengan menentukan nilai rata-rata hitung dan persen/proposisi.

Teknik pengumpulan data dilakukan untuk mendapatkan data relevan terkait dengan penelitian ini. Teknik pengumpulan data yang dilakukan adalah sebagai berikut:

1. Dokumentasi

2. Teknik wawancara

3. Studi Pustaka

Analisis data menggunakan statistik deskriptif yang digunakan untuk menganalisis data dengan cara mendeskripsikan atau menggambarkan data yang telah terkumpul sebagaimana adanya tanpa maksud membuat kesimpulan yang berlaku untuk umum atau generalisasi.

\section{Pertumbuhan}

Untuk menghitung pertumbuhan dari pendapatan pajak hotel digunakan rumusan (Arsyad dalam Rahayuningsih, 2009:41) sebagai berikut:

$$
\begin{aligned}
& X t-X(t-1) \\
& \frac{G x \square \quad X 100 \%}{X(t \square)}
\end{aligned}
$$

Keterangan:

$\mathrm{Gx} \quad=$ Pertumbuhan pajak hotel pertahun

$\mathrm{Xt} \quad=$ Realisasi pendapatan pajak hotel pada tahun tertentu X(t-

1) $=$ Realisasi pendapatan pajak hotel pada tahun sebelumnya

Berdasarkan hasil analisis pertumbuhan pajak hotel, dapat tergambarkan suatu perbedaan antara pendapatan tiap tahunnya, sehingga dari data tersebut dapat disimpulkan pertumbuhan pajak hotel.

\section{Efektifitas}

Besarnya efektifitas pajak dapat dihitung dengan rumus sebagai berikut (Halim, 2004:93):

$$
\text { Efektifitas }=\frac{\text { realisasi pendapatan } X 100}{\text { pendapatan }} \% \text { target }
$$

Dikatakan efektif apabila proses kegiatan mencapai tujuan dan sasaran akhir kebijakan (spending wisely). Semakin besar output yang dihasilkan terhadap pencapaian tujuan dan sasaran yang ditentukan, maka semakin efektif proses kerja suatu unit organisasi.

\section{Efisiensi}

Efisiensi berhubungan dengan besarnya biaya pemungutan yang dikeluarkan atas hasil realisasi yang diterima. Apabila dikaitkan dengan efisiensi pajak hotel, sebagai berikut (Halim, 2004:93):

$$
\text { Efisiensi }=\frac{\text { biaya pemungutan } X 100 \% \text { realisasi }}{\text { pendapatan }}
$$

Apabila hasil yang dicapai kurang dari 1 atau 100\% (<1 atau 100\%) dikatakan efisien dan apabila hasil yang dicapai lebih dari 1 atau 100\% (> 1 atau 100\%) dikatakan tidak efisien.

\section{Kontribusi}

Dalam menghitung kontibusi pajak hotel terhadap Pajak Daerah maka digunakan rumus sebagai berikut (Budiyuwono, 1995: 160):

$$
\mathrm{Pn}=\frac{\mathrm{QXnX}}{\mathrm{QYn}} 100 \%
$$

Keterangan :

P : Kontribusi Pajak Hotel Terhadap Pajak Daerah 


$$
\begin{array}{ll}
\text { QX } & \text { : Realisasi Penerimaan Pajak Hotel } \\
\text { QY } & \text { : Realisasi Penerimaan Pajak Daerah } \\
\text { n } & \text { : Tahun (Periode) tertentu }
\end{array}
$$

\section{Analisis Trend}

Analisis trend adalah analisis yang dilakukan dengan cara membandingkan pos-pos laporan keuangan dalam dua periode atau lebih. Perbandingan dibuat dalam persentase yang tahun pertamanya ditetapkan sebagai patokan sebesar $100 \%$, dan tahun-tahun berikutnya dibandingkan dengan data tahun dasar tersebut.

\section{HASIL DAN PEMBAHASAN}

\section{Hasil Penerimaan Pajak Hotel di Kota Palu}

Pemungutan pajak hotel tidak secara langsung dapat dipungut oleh Dinas Pendapatan Daerah terhadap wajib pajak, tetapi pemungutannya dilakukan oleh pihak bagian resepsionis hotel atas pembayaran pelayanan jasa penginapan. Oleh karena itu, pajak hotel disebut pajak tidak langsung (Halim, 2001:349).

Kriteria yang dapat dijadikan sebagai ukuran untuk menentukan hotel maupun penginapan yang dapat dijadikan sebagai sasaran pajak hotel sebagai berikut :

1. Fasilitas penginapan jangka pendek seperti cottage, motel, wisma, losmen, penginapan, kos dengan fasilitas seperti penginapan dengan jumlah kamar minimal 10 kamar.

2. Pelayanan penunjang seperti telepon, fotokopi, cuci/setrika, taksi yang disediakan dan dikelola oleh hotel.

3. Fasilitas olahraga dan hiburan seperti tempat kebugaran, kolam renang, tenis, golf, yang dikelola oleh hotel dan dipergunakan untuk tamu hotel.

4. Jasa persewaan gedung untuk kegiatan acara atau pertemuan.

5. Pengenaan pajak hotel apabila pendapatan atau omset sebesar Rp 3.000.000/bulan

6. Masa pajak adalah jangka waktu yang lamanya 1 (satu) bulan kalender atau jangka waktu lain yang diatur dengan Peraturan Walikota paling lama 3 (tiga) bulan kalender.

Sedangkan yang tidak termasuk dalam sasaran Pajak Hotel berdasarkan Perda Kota Palu Nomor 11 tahun 2011 yaitu:

a. Jasa tempat tinggal asrama yang diselenggarakan oleh Pemerintah dan Pemerintah Daerah;

b. Jasa sewa apartemen, kondominium, dan sejenisnya;

c. Jasa tempat tinggal di pusat pendidikan atau kegiatan keagamaan;

d. Jasa tempat tinggal di rumah sakit, asrama perawat, panti jompo, panti asuhan, dan panti sosial lainnya yang sejenis; dan

e. Jasa biro perjalanan atau perjalanan wisata yang diselenggarakan oleh Hotel yang dapat dimanfaatkan oleh umum.

Data hotel yang digunakan dalam penelitian ini adalah berdasarkan data pajak hotel yang terdaftar dan sesuai dengan ketentuan Dinas Pendapatan Pengelolaan Keuangan dan Aset Daerah Kota Palu. Jumlah wajib pajak hotel ditahun 2014 mencapai 157 unit.

\section{Analisis Pertumbuhan Pendapatan Pajak Hotel Kota Palu}

\begin{tabular}{|c|c|c|c|c|}
\hline \multirow{2}{*}{ No } & \multirow{2}{*}{ Tahun } & \multicolumn{2}{|c|}{ Pajak Hotel } & \multirow{2}{*}{ Keterangan } \\
\hline & & Realisasi (Rp) & Pertumbuhan (\%) & \\
\hline 1 & 2010 & $1.703 .852 .000,00$ & \multirow{6}{*}{$\begin{array}{c}- \\
12,26 \\
78,50 \\
45,02 \\
75,14 \\
\mathbf{5 2 , 7 3}\end{array}$} & \multirow{6}{*}{$\begin{array}{l}\text { Secara rill terlihat } \\
\text { meningkat namun } \\
\text { secara persentase } \\
\text { peningkatannya } \\
\text { berfluktuasi }\end{array}$} \\
\hline 2 & 2011 & $1.912 .852 .881,00$ & & \\
\hline 3 & 2012 & $3.414 .632 .416,00$ & & \\
\hline 4 & 2013 & $4.952 .210 .445,00$ & & \\
\hline 5 & 2014 & $8.673 .418 .273,64$ & & \\
\hline \multicolumn{3}{|c|}{ Rata-Rata } & & \\
\hline
\end{tabular}

Untuk melihat pertumbuhan dari pendapatan pajak hotel Kota Palu dapat dilihat pada tabel 3. Tabel 3 Pertumbuhan Pendapatan Pajak Hotel Kota Palu

Sumber: Data diolah September, 2016 
Angka persentase pendapatan pajak hotel yang berfluktuasi disebabkan oleh tingkat hunian pada hotel yang tidak menentu. Terkadang tamu yang datang ramai dan terkadang tamu yang datang sepi sehingga berpengaruh terhadap omset dari hotel itu sendiri dan secara otomatis mempengaruhi penerimaan dari pajak hotel tersebut

\section{Analisis Efektifitas Pendapatan Pajak Hotel Kota Palu}

Efektifitas dalam hal ini, menggambarkan kemampuan pemerintah dalam mengelola penerimaan dari pajak hotel dengan melihat besarnya realisasi dengan target yang ditentukan. Semakin besarnya realisasi yang dicapai dengan melebihi target yang ditentukan, maka angka persentase akan mencapai tingkat efektifitas. Artinya, dalam kategori apabila rasio yang dicapai sebesar 1 atau $100 \%$ adalah efektif dan apabila melebihi dari dari hasil 1 atau $100 \%$ adalah sangat efektif. Kemudian sebaliknya, jika angka persentase kurang dari 1 atau 100\% maka akan tidak efektif atau semakin tidak efektif. Untuk mengukur efektifitas dari pendapatan pajak hotel Kota Palu dapat dilihat pada tabel 4 sebagai berikut :

Tabel 4Efektifitas Pajak Hotel Kota Palu

\begin{tabular}{|r|c|c|c|c|c|}
\hline \multirow{2}{*}{ No } & \multirow{2}{*}{ Tahun } & \multicolumn{2}{|c|}{ Pajak Hotel } & \multirow{2}{*}{ Persentase (\%) } & \multirow{2}{*}{ Keterangan } \\
\cline { 3 - 4 } & & Target (Rp) & Realisasi (Rp) & & \\
\hline 1 & 2010 & $1.488 .241 .000,00$ & $1.703 .852 .000,00$ & 114,48 & Sangat efektif \\
\hline 2 & 2011 & $1.688 .241 .000,00$ & $1.912 .852 .881,00$ & 113,30 & Sangat efektif \\
\hline 3 & 2012 & $2.235 .000 .000,00$ & $3.414 .632 .416,00$ & 152,77 & Sangat efektif \\
\hline 4 & 2013 & $3.000 .000 .000,00$ & $4.952 .210 .445,00$ & 165,07 & Sangat efektif \\
\hline 5 & 2014 & $7.250 .000 .000,00$ & $8.673 .418 .273,64$ & 119,63 & Sangat efektif \\
\hline \multicolumn{2}{|c|}{ Rata-rata } & $\mathbf{1 3 3 , 0 5}$ & Sangat Efektif \\
\hline
\end{tabular}

Sumber: Data diolah September, 2016

Secara nilai rata-rata pencapaian tingkat efektifitas pajak hotel, maka angka yang dihasilkan adalah 133,05\% dengan kategori sangat efektif. Artinya bahwa kinerja pemerintah daerah dalam mengelola pemungutan pajak hotel selama 5 tahun sudah sangat efektif. Hal ini disebabkan oleh proses pengendalian dan pengawasan yang baik terhadap pemungutan pajak hotel di lapangan. Walaupun dikategorikan sangat efektif, pemerintah daerah selalu diharuskan untuk terus berupaya mengelola secara intensif terhadap potensi hotel, sehingga dari hasil realisasi diharapkan dapat meningkatkan pendapatan dari pajak hotel.

\section{Analisis Efisiensi Pendapatan Pajak Hotel Kota Palu}

Pelaksanaan kegiatan daerah jika ditinjau dari pengelolaanya, dimana pemerintah daerah selalu berupaya semaksimal mungkin menghasilkan realisasi yang optimal dengan biaya yang minimal. Hal inilah yang erat kaitannya dengan efisiensi atau daya guna. Efisiensi berbanding terbalik dengan efektifitas, dimana dalam asumsi apabila angka persentase menunjukkan kurang dari 1 atau $100 \%$ dikatakan efisien dan apabila angka yang diperlihatkan semakin kecil dari tahun sebelumnya maka dikatakan semakin efisien dan sebaliknya.

Berdasarkan keputusan Menteri Dalam Negeri No. 35 tahun 2002 tentang Pedoman Alokasi Biaya pemnungutan Pajak Daerah, dimana biaya pungut untuk pajak ditetapkan paling tinggi sebesar 5\% dari hasil realisasi yang diterima. Kemudian diatur dalam Peraturan Pemerintah Daerah Kota Palu Nomor 7 Tahun 2007, ditetapkan besarnya biaya pungut pajak hotel sebesar 5\% dari hasil realisasi. Biaya pungutan itu mulai dari penghimpunan data objek dan subjek pajak, penentuan besarnya pajak terutang, sampai kegiatan penagihan pajak kepada wajib pajak, dan terakhir pengawasan terhadap penyetoran pajak. Untuk mengetahui efisiensi dari pajak hotel dapat dilihat pada tabel 4.3 sebagai berikut: 
Tabel 5 Efisiensi Pajak Hotel Kota Palu

\begin{tabular}{|c|c|c|c|c|c|}
\hline \multirow{2}{*}{ No } & \multirow{2}{*}{ Tahun } & \multicolumn{2}{|c|}{ Pajak Hotel } & \multirow{2}{*}{ Nilai } & \multirow{2}{*}{ Keterangan } \\
& & Realisasi (Rp) & Biaya pungut (Rp) & & \\
\hline $\mathbf{1}$ & 2010 & 1.703 .852 .495 & 85.192 .625 & 0,05 & Efisien \\
\hline $\mathbf{2}$ & 2011 & 1.912 .852 .881 & 95.642 .644 & 0,05 & Efisien \\
\hline $\mathbf{3}$ & 2012 & 3.414 .632 .416 & 170.731 .621 & 0,05 & Efisien \\
\hline $\mathbf{4}$ & 2013 & 4.952 .210 .445 & 247.610 .522 & 0,05 & Efisien \\
\hline $\mathbf{5}$ & 2014 & $8.673 .418 .273,64$ & 433.670 .914 & 0,05 & Efisien \\
\hline \multicolumn{7}{|l}{ Rata-rata } & $\mathbf{0 , 0 5}$ & Efisien \\
\hline
\end{tabular}

Sumber: Data diolah September, 2016

Berdasarkan Tabel di atas, realisasi pendapatan pajak hotel meningkat setiap tahunnya diikuti dengan meningkatnya biaya pungut yang dikeluarkan dalam memungut pajak. Perbandingan setiap tahunnya oleh realisasi pajak hotel dan biaya pungut menunjukkan nilai 0,05 atau 5\%. Jika disesuaikan dengan kategori efisiensi, maka pengelolaan terhadap pajak hotel dikatakan efisien. Hal ini disebabkan oleh besarnya biaya pungut yang ditetapkan hanya sebesar 5\%. Oleh karena itu, besarnya realisasi yang diterima atau kecilnya realisasi yang diterima tidak akan berpengaruh pada tingkat efisiensi pajak hotel. Artinya besar kecilnya realisasi pasti akan tetap efisien.

\section{Analisis Kontribusi Pendapatan Pajak Hotel Terhadap Pajak Daerah}

Metode ini digunakan dengan maksud untuk menghitung seberapa besar kontribusi yang diberikan dari pendapatan pajak hotel terhadap pajak daerah, dengan cara membandingkan antara pencapaian atau realisasi dari penerimaan pajak hotel dengan pencapaian atau realisasi pajak daerah. Dengan begitu, dapat diketahui sumbangan pajak hotel berapa persen (\%) dalam meningkatkan pajak daerah Kota Palu. Kontibusi pajak hotel dapat di lihat pada table 6 sebagai berikut :

Tabel 6 Kontribusi Pajak Hotel Terhadap Pajak Daerah Kota Palu

\begin{tabular}{|c|c|c|c|c|}
\hline No & Tahun & $\begin{array}{c}\text { Realisasi Pajak } \\
\text { Hotel (Rp) }\end{array}$ & $\begin{array}{c}\text { Realisasi Pajak } \\
\text { Daerah }(\mathbf{R p})\end{array}$ & $\begin{array}{c}\text { Kontribusi ke Pajak } \\
\text { Daerah }(\%)\end{array}$ \\
\hline 1 & 2010 & $1.703 .852 .495,00$ & $18.208 .753 .733,00$ & 9,36 \\
\hline 2 & 2011 & $1.912 .852 .881,00$ & $26.707 .303 .741,00$ & 7,16 \\
\hline 3 & 2012 & $3.414 .632 .416,00$ & $48.528 .373 .781,50$ & 7,04 \\
\hline 4 & 2013 & $4.952 .210 .445,00$ & $58.157 .337 .277,00$ & 8,52 \\
\hline 5 & 2014 & $8.673 .418 .273,64$ & $79.075 .428 .920,85$ & 10,97 \\
\hline \multicolumn{3}{|l}{ Rata-rata }
\end{tabular}

Sumber: Data diolah September, 2016

Dari tabel 6 dapat diketahui rata-rata kontribusi pajak hotel di kota Palu terhadap pajak daerah sebesar 8,61\%. Dapat disimpulkan bahwa pendapatan pajak daerah sebesar 8,61\% berasal dari pajak hotel, sisanya berasal dari pajak Restoran, hiburan, reklame, air tanah, parkir, penerangan jalan, dan PBB Perkotaan.

\section{Analisis Trend Pendapatan Pajak Hotel}

Dalam analisis trend ini, apabila hal yang diteliti menunjukkan gejala kenaikan maka trend yang dimiliki menunjukkan rata-rata pertambahan atau disebut trend positif. Sedangkan apabila hal yang diteliti menunjukkan gejala semakin berkurang, maka trend yang kita miliki menunjukkan rata-rata penurunan atau disebut trend negatif (Dwi Nurul Utami,2011:47).

Untuk menggambarkan perkembangan trend pendapatan pajak hotel tahun 2015-2017, dapat dilihat pada gambar 2 sebagai berikut: 


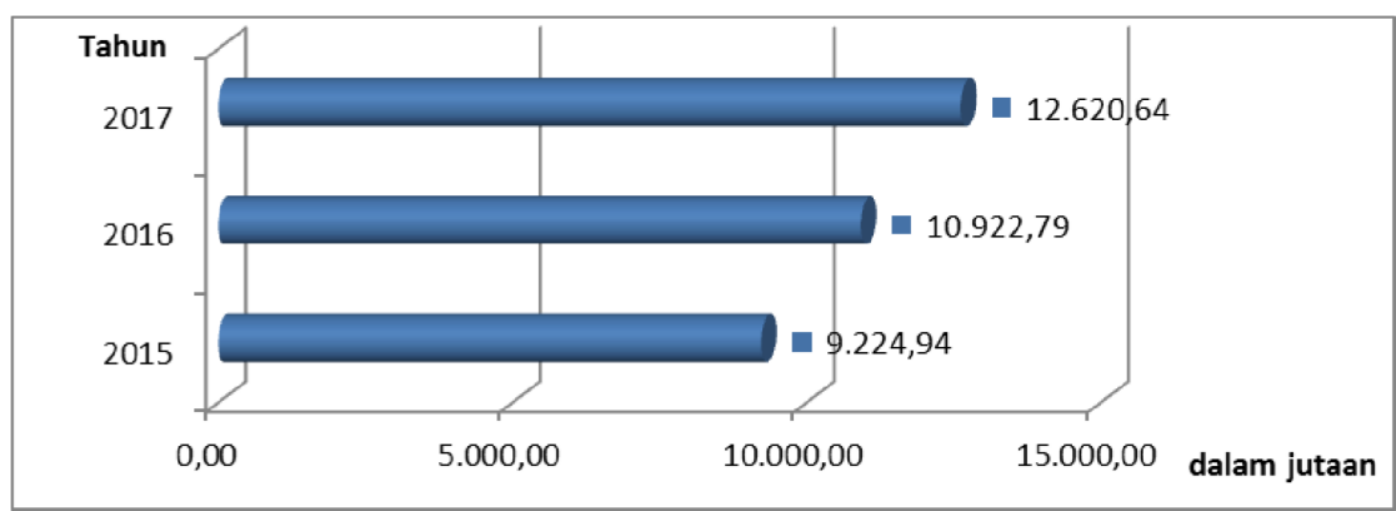

Sumber: Data diolah September, 2016

Gambar 2

Perkembangan Trend Pendapatan Pajak Hotel Tahun 2015-2017 Kota Palu

Berdasarkan Gambar di atas, digambarkan realisasi yang terus meningkat setiap tahunnya. Persamaan Trend menunjukkan bahwa untuk tahun-tahun berikutnya penerimaan Pajak Hotel cenderung semakin meningkat ini ditandai dengan slope positif persamaan trend diatas dan hasil uji statistiknya selama 5 tahun periode pengamatan yakni dari tahun 2010 sampai dengan 2014.

\section{KESIMPULAN DAN SARAN}

\section{Kesimpulan}

Berdasarkan hasil penelitian dan pembahasan, maka dapat ditarik kesimpulan bahwa :

1. Tingkat pertumbuhan pendapatan pajak hotel di Kota Palu secara riil meningkat, namun secara persentase peningkatannya berfluktuasi dengan rata-rata pertumbuhan sebesar 52,73\%. Hal ini disebabkan oleh jumlah tamu yang datang menginap di hotel terkadang ramai dan terkadang sepi.

2. Pendapatan pajak hotel Kota Palu secara rata-rata dapat dikatakan efektif yaitu sebesar $133,05 \%$. Hal ini disebabkan oleh proses pengendalian dan pengawasan yang baik terhadap pemungutan pajak hotel di lapangan.

3. Pendapatan pajak hotel secara rata-rata dapat dikatakan efisien yaitu sebesar 0,05 atau $5 \%$. Hal ini disebabkan oleh biaya pungut yang ditetapkan sebesar 5\% dari hasil realisasi. Jadi, besar atau kecilnya realisasi yang didapatkan pasti akan tetap efisien.

4. Dari hasil realisasi pajak hotel selama 5 tahun, kontribusi yang diberikan terhadap pajak daerah rata-rata sebesar $8,61 \%$. Kontribusi ini menunjukkan besarnya kemampuan pajak hotel dalam meningkatkan pajak daerah Kota Palu.

\section{Saran}

Berdasarkan hasil penelitian tentang Analisis Penerimaan Pajak Hotel Terhadap Peningkatan Pajak Daerah Kota Palu, maka ada beberapa usulan serta saran untuk Pemerintah Daerah khususnya Dinas Pendapatan Pengelolaan Keuangan dan Aset Daerah (DPPKAD) Kota Palu, yang sebagai koordinator pengelolaan penerimaan keuangan daerah sekaligus pemungut langsung dari pajak hotel kota palu adalah :

1. Pendataan kembali hotel-hotel yang ada di Kota Palu. Dari daftar wajib pajak hotel yang ada pada Dinas Pendapatan Pengelolaan Keuangan dan Aset Daerah (DPPKAD) belum semua terdata, karena pada kenyataannya pengusaha hotel dan penginapan masih ada yang belum mendaftarkan usahanya.

2. Masih banyak potensi-potensi hotel yang terpendam. Oleh karena itu, diharapkan dari pihak pemerintah daerah untuk lebih meningkatkan upayanya dalam mengelola potensi yang ada pada hotel sehingga dari pengelolaanya diharapkan dapat berpengaruh positif dalam menambah pendapatan dari pajak hotel terutama perbaikan sistem karena jika pemerintah daerah memiliki sistim perpajakan daerah yang memadai, maka daerah dapat menikmati pendapatan dari sektor pajak yang cukup besar. 
3. Untuk meningkatkan pertumbuhan, efektifitas, efisiensi, serta Kontribusi pajak hotel terhadap pajak daerah Kota Palu, Dinas Pendapatan Pengelolaan Keuangan dan Aset Daerah (DPPKAD) harus lebih menggalakkan kegiatan sosialisasi maupun edukasi kepada masyarakat luas khususnya para wajib pajak mengenai pentingnya pajak agar kesadaran membayar pajak semakin meningkat, selain itu DPPKAD Kota Palu diharapkan dapat meningkatkan sumber daya manusia aparatur melalui kegiatan diklat maupun studi banding dengan instansi luar daerah kota Palu.

4. Disarankan untuk peneliti selanjutnya, agar dapat mengkaji lebih luas lagi tentang pendapatan pajak hotel Kota Palu dengan memperhatikan perkembangan jumlah hotel yang belum terdaftar.

\section{REFERENSI}

Budiyuwono, Nugroho, 1995. Pengantar Statistik Ekonomi dan Perusahaan, Binarupa Aksara, Jakarta.

Dwi Nurul Utami. 2011. Analisis Penerimaan Retribusi Izin Usaha jasa Telekomunikasi Di Kota Palu,

Skripsi Universitas Tadulako, Palu.

Halim. 2001. Akuntansi dan pengendalian keuangan daerah, UPP AMP YKPN, Yogyakarta. 2004. Manajemen Keuangan Daerah, Edisi Revisi. AMP YKPN. Yogyakarta. 2007. Akuntansi Keuangan daerah. Salemba Empat. Jakarta.

Peraturan Daerah Kota Palu Nomor 1 Tahun 2011. Tentang Pajak Daerah.

Peraturan Pemerintah Repuublik Indonesia Nomor 65 Tahun 2001, Tentang Pajak Daerah.

Peraturan Menteri Dalam Negeri Nomor 35 Tahun 2002. Tentang Pedoman Alokasi Biaya Pemungutan Pajak Daerah.

Rahayuningsih. 2009. Analisis Efektivitas Pajak Reklame Terhadap Peningkatan Pendapatan Asli Daerah (PAD) di Kabupaten Banyuwangi. Jurnal Ilmiah PROGRESIF , Volume 6, Nomor 16, April 2009.

Undang-Undang Republik Indonesia Nomor 28 Tahun 2009, Revisi dari Undang-Undang Nomor 34 Tahun 2000. Tentang Pajak Daerah dan Retribusi Daerah.

Undang-Undang Republik Indonesia Nomor 32 Tahun 2004, Revisi dari Undang-Undang Nomor 22 Tahun 1999. Tentang Pemerintah Daerah.

Undang-Undang Republik Indonesia Nomor 33 Tahun 2004, Tentang Perimbangan Keuangan Antara Pemerintah Pusat dan Pemerintah Daerah.

Undang-Undang Republik Indonesia Nomor 28 Tahun 2009, Revisi dari Undang-Undang Nomor 34 Tahun 2000. Tentang Pajak Daerah dan Retribusi Daerah. 